\title{
PENINGKATAN KEMAMPUAN LITERASI SAINS DAN HASIL BELAJAR SISWA PADA POKOK BAHASAN LINGKUNGAN DENGAN MENERAPKAN PEMBELAJARAN DISCOVERY LEARNING DI KELAS VII SMP NEGERI 2 BINJAI
}

\author{
Nurhayati \\ Guru IPA SMP Negeri 2 Binjai \\ JI. Sultan Hasanuddin No 22, Kota Binjai, Kab. Langkat, Sumatera Utara 20714 \\ E-mail: nhnurhayati73@gmail.com
}

\begin{abstract}
ABSTRAK
Tujuan penelitian ini meningkatkan keterampilan literasi sains dan hasil belajar siswa pada materi pencemaran lingkungan dengan Model Pembelajaran Discovery Learning di kelas VII SMP Negeri 2 Binjai. Desain Penelitian ini adalah Penelitian Tindakan Kelas menggunakan model penelitian kemmis dan taggart, yaitu berbentuk spiral dari siklusyang satu ke siklus yang berikutnya. Setiap siklus meliputi planing (rencana), action (tindakan), observation (Pengamatan), dan reflektion (refleksi). Adapun hasil penelitian ini adalah: 1) Pada Siklus I penerapan model pembelajaran Discovery learning memperoleh hasil belajar siswa dari 26 orang siswa diperoleh 18 orang yang tuntas dengan $69,2 \%$ dan 8 orang yang tidak tuntas dengan $30,8 \%$. Observasi keterampilan literasi sains penerapan model pembelajaran Discovery learning, diperoleh dari 26 siswa yang ada di kelas VII SMP Negeri 2 Binjai Kab. Langkat, sebanyak 11 orang siswa keterampilan literasi sainsnya dikategorikan Baik, dan 11 orang siswa keterampilan literasi sainsnya dikategorikan Cukup, dan 4 orang siswa keterampilan literasi sainsnya dikategorikan Kurang; 2) Pada Siklus II diperoleh hasil belajar dari ari 26 orang siswa diperoleh 23 orang yang tuntas dengan 88,5\% dan 3 orang yang tidak tuntas dengan 11,5\%. hasil observasi keterampilan literasi sains penerapan model pembelajaran Discovery learning, diperoleh dari 26 siswa yang ada di kelas VII SMP Negeri 2 Binjai Kab. Langkat, sebanyak 21 orang siswa keterampilan literasi sainsnya dikategorikan Baik, dan 5 orang siswa keterampilan literasi sainsnya dikategorikan Cukup. Dapat ditarik kesimpulan bahwa penerapan model pembelajaran Discovery learning dapat meningkatkan hasil belajar siswa dan keterampilan literasi sains siswa Kelas VII-1 SMP Negeri 2 Binjai Kab. Langkat TP. 2017/2018.
\end{abstract}

Kata Kunci: Model Pembelajaran, Discovery Learning, IPA

\begin{abstract}
The purpose of this study is to improve scientific literacy skills and student learning outcomes in environmental pollution material with Discovery Learning Learning Model in class VII of Binjai State Middle School 2. The design of this study is Class Action Research using the Kemmis and Taggart research model, which is spiral in shape from one cycle to the next. Each cycle includes planing, action, observation, and reflection. The results of this study are: 1 ) In the first cycle the implementation of the Discovery learning learning model obtained student learning outcomes from 26 students obtained by 18 people who completed $69.2 \%$ and 8 people who did not complete with $30.8 \%$. Observation of science literacy skills in the application of the learning model of Discovery learning, obtained from 26 students in class VII of Binjai State Middle School 2 District. Langkat, as many as 11 students in their scientific literacy skills are categorized as Good, and 11 students in their scientific literacy skills are categorized as Enough, and 4 students in their science literacy skills are categorized as Less; 2 ) In Cycle II learning outcomes obtained from 26 students were obtained by 23 people who completed $88.5 \%$ and 3 people who did not complete with $11.5 \%$. the results of the observation of science literacy skills the application of the learning model of Discovery learning, obtained from 26 students in class VII of Binjai State Middle School 2 District. Langkat, 21 students of science literacy skills are categorized as Good, and 5 students of science literacy skills are categorized as Enough. It can be concluded that the application of learning models Discovery learning can improve student learning outcomes and science literacy skills of students of Class VII-1 Binjai State Middle School 2 District. TP level. 2017/2018.
\end{abstract}




\section{Keywords : Discovery Learning, Learning Models, natural sciences}

\section{PENDAHULUAN}

Ilmu Pengetahuan Alam (IPA) berkaitan dengan cara mencari tahu tentang alam secara sistematis, sehingga IPA bukan hanya penguasaan kumpulan pengetahuan yang berupa fakta-fakta, konsep-konsep, atau prinsipprinsip saja tetapi juga merupakan suatu proses penemuan (Depdiknas, 2006). Pemerintah pada tahun 2013 melalui Kementerian Pendidikan dan Kebudayaan menerapkan kurikulum baru yaitu Kurikulum 2013 untuk menyempurnakan kurikulum sebelumnya yaitu Kurikulum Tingkat Satuan Pendidikan (KTSP).

Pembelajaran harus mengarahkan siswa untuk memiliki keterampilan proses sains dengan melatih siswa melakukan pengamatan, mengumpulkan data, berhipotesis, menguji hipotesis, dan menganalisis untuk membangun konsep sendiri berdasarkan pengetahuan yang sudah dimilikinya (Yunia,2016). Melatih keterampilan proses sains siswa melibatkan keterampilan mental, intelektual, fisik dan sosial untuk membangun kemampuan kognitif sehingga siswa memiliki kompetensi pengetahuan, keterampilan dan sikap yang dapat diterapkan dalam kehidupan sehari-hari. guru (teacher-centered) sehingga siswa tidak memperoleh pengalaman belajar secara langsung. Sejalan dengan hal tersebut, Isnawati (2014) menyatakan bahwa dalam proses belajar mengajar, guru cenderung memilih pendekatan, metode, dan strategi pembelajaran yang hanya memacu siswa untuk mengingat dan menghafalkan konsep-konsep yang ada.

Berdasarkan supervisi yang dilakukan kepala sekolah SMP Negeri 2 Binjai Kab. Langkat, dalam proses pembelajaran yang dilakukan belum menerapkan pembelajaran aktif-mencari, pembelajaran masih teacher oriented sehingga tidak membuat siswa aktif dalam proses pembelajaran, siswa lebih aktif apabila pembelajaran dilakukan dengan melakukan kegiatan percobaan namun kegiatan percobaan masih jarang dilakukan. Padahal jika percobaan dilakukan dalam pembelajaran IPA tentu sangat baik selain meningkatkan keatifan siswa juga meningkatkan keterampilan berliterasi. Keterampilan literasi sains menurut Simatupang, et al (2017) dilihat dari aspek sikap dan berpikir ilmiah, dengan kriteria: Sikap ingin tahu; Berpikiran terbuka dan kerjasama; Berpikir kritis; Ketekunan, Respek Terhadap data/Fakta. Diketahui bahwa siswa di SMP Negeri 2 Binjai Kab. Langkat Khusunya kelas VII sangat rendah literasi sainsnya jika dilhat dari kriteria tersebut, oleh karena itu keterampilan literasi sains perlu ditingkatkan.

Hasil supervise dan refleksi guru ini menjadi bahan diskusi yang dilakukan ditingkat sekolah untuk memperbaiki pembelajaran rendahnya keterampilan literasi siswa ini juga berdampak pada hasil belajar siswa, adapun akar masalah dari hal tersebut yaitu: 1) model pembelajaran yang diterapkan guru belum maksimal dan tidak sesuai dengan materi yang ada; 2) keterampilan literasi sains memang belum maksimal ditagih dari siswa; 3) siswa merasa bosan jika mengikuti mata pelajaran IPA.

Model pembelajaran yang cocok digunakan untuk melibatkan siswa dalam mendapatkan pengalaman pembelajaran secara langsung dan diterapkan dalam melatih keterampilan proses sains siswa yaitu model pembelajaran discovery learning. Pembelajaran discovery learning merupakan suatu model yang dikembangkan untuk melibatkan siswa secara aktif dengan melakukan serangkaian kegiatan penemuan (Hosnan, 2014). Dengan melakukan kegiatan penemuan siswa akan melalui proses "mencari tahu" dan "melakukan" sehingga siswa dapat memperoleh pemahaman yang lebih mendalam dan pembelajaran yang dilakukan akan lebih bermakna. Dalam pembelajaran discovery learning, peran guru adalah sebagai pembimbing/fasilitator bagi siswa untuk memecahkan masalah. Namun, dalam pelaksanaannya proses pembelajaran IPA yang dilakukan masih belum memberikan pengalaman belajar secara langsung dan belum melatihkan keterampilan proses sains, sehingga keterampilan proses sains siswa masih rendah. Proses pembelajaran yang dilaksanakan masih berpusat pada guru (teacher-centered) sehingga siswa tidak memperoleh pengalaman belajar secara langsung.

Berdasarkan latar belakang diatas maka peneliti tertarik untuk melakukan perbaikan pembelajaran dengan melaksanakan Penelitian Tindakan Kelas (PTK) di SMP Negeri 2 Binjai Kab. Langkat. Pada mata pelajaran IPA yang berjudul "Peningkatan Kemampuan Literasi Sains dan Hasil Belajar Siswa Pada Pokok Bahasan Pencemaran Lingkungan Dengan Menerapkan Model Pembelajaran Discovery Learning di Kelas VII SMP Negeri 2 Binjai Kab. Langkat TP.2017/2018".

\section{METODE PENELITIAN}


Penelitian Tindakan Kelas merupakan ragam penelitian pembelajaran yang berkonteks kelas yang dilaksanakan oleh guru untuk memecahkan masalahmasalah pembelajaran yang dihadapi oleh guru, memperbaiki mutu dan hasil pembelajaran dan mencoba hal-hal baru dalam pembelajaran demi peningkatan mutu dan hasil pembelajaran. PTK mempunyai karakteristik tersendiri yang membedakan dengan penelitian yang lain, diantaranya yaitu : masalah yang diangkat adalah masalah yang diahadapi oleh guru dikelas dan adanya tertentu untuk memperbaiki proses belajar mengajar dikelas. Model penelitian kemmis dan taggart (Arikunto, 2010), yaitu berbentuk spiral dari siklusyang satu ke siklus yang berikutnya. Setiap siklus meliputi planing (rencana), action (tindakan), observation (Pengamatan), dan reflektion (refleksi).

\section{HASIL DAN PEMBAHASAN}

Penelitian Tindakan Kelas yang dilaksanakan untuk meningkatkan keterampilan literasi sains dan hasil belajar siswa dengan menerapkan model pembelajaran discovery learning mata pelajaran IPA kelas VII SMP Negeri 2 Binjai Kab. langkat Tahun Pelajaran 2017/2018. Sebelum melaksanakan penelitian siklus I sebanyak dua pertemuan dilakukan langkah-langkah yang dilakukan peneliti yaitu: 1) menyusun rancangan pelaksanaan pembelajaran (RPP), 2) menyusun media pembelajaran yang akan digunakan, 3) sumber belajar, dan bahan yang dibutuhkan dalam melaksanakan pembelajaran, dan 4) membuat lembar observasi aktivitas siswa.

\section{Siklus I}

Pada siklus 1 ini hasil belajar siswa sudah meningkat cukup baik, namun masih belum tercapai ketuntasan klasikal.

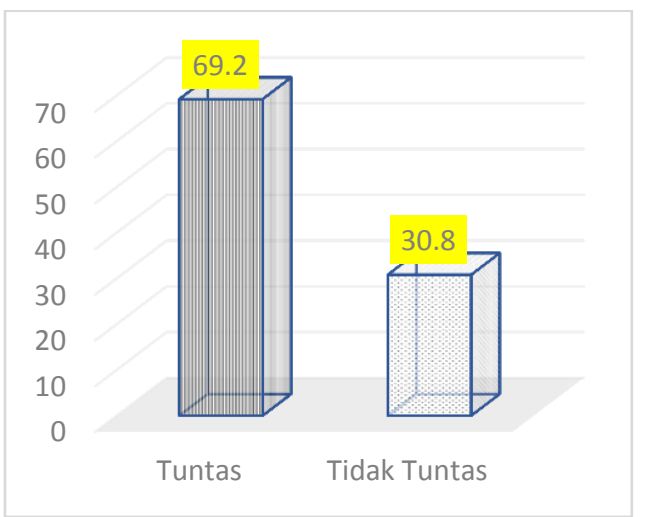

Gambar.1 Hasil Belajar IPA Siklus I
Dari gambar 1 diatas diperoleh hasil belajar IPA kelas VII SMP Negeri 2 Binjai Kab. Langkat Tahun Pelajaran 2017/2018, dapat ditarik kesimpulan bahwa pembelajaran dengan menggunakan model pembelajaran discovery learning dalam meningkatkan hasil belajar dari 26 orang siswa diperoleh 18 orang yang tuntas dengan $69,2 \%$ dan 8 orang yang tidak tuntas dengan $30,8 \%$. Beberapa temuan yang menjadi bahan refleksi pada siklus I yaitu siswa terkendalam dalam mengumpulkan data dan mengolah data. Penerapan model pembelajaran ini juga mengukur kterampilan literasi sains siswa, hasil observasi keterampilan literasi sains. Hasil observasi keterampilan literasi sains penerapan model pembelajaran Discovery learning, diperoleh dari 26 siswa yang ada di kelas VII SMP Negeri 2 Binjai Kab. Langkat, sebanyak 11 orang siswa keterampilan literasi sainsnya dikategorikan Baik, dan 11 orang siswa keterampilan literasi sainsnya dikategorikan Cukup, dan 4 orang siswa keterampilan literasi sainsnya dikategorikan Kurang. Dari data tersebut diketahui ada 3 aspek yang masih lemah yaitu: 1) rasa ingin tahu siswa, 2) respon terhadap data/fakta; 3) komunikasi siswa masih kurang. Dan ketiga aspek ini masih perlu diperhatikan guru untuk meningkatkannya.

\section{Siklus II}

Perencanaan siklus II berdasarkan kendala dan kelemahan yang ditemukan pada siklus I dari observasi penerapan model pembelajaran Discovery learning, agar kendala dan kelemahan pada siklus I tidak terjadi lagi maka guru berupaya semaksimal mungkin untuk mengontrol kegiatan proses belajar mengajar dan memberikan motivasi kepada siswa. Hasil belajar siswa tertera pada gambar 2 dibawah ini:

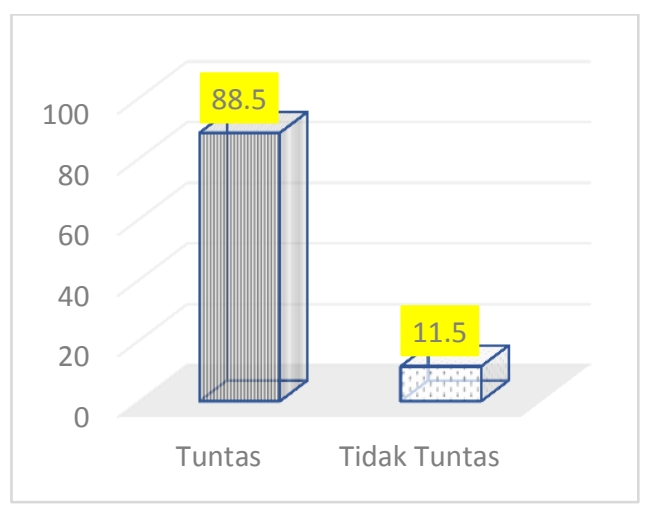

Gambar 2. Hasil Belajar IPA Siklus II 
Gambar 2 diatas diperoleh hasil belajar IPA kelas VII SMP Negeri 2 Binjai Kab. Langkat Tahun Pelajaran 2017/2018, dapat ditarik kesimpulan bahwa pembelajaran dengan menggunakan model pembelajaran discovery learning dalam meningkatkan hasil belajar siswa dari 26 orang siswa diperoleh 23 orang yang tuntas dengan $88,5 \%$ dan 3 orang yang tidak tuntas dengan $11,5 \%$. Pada siklus II terjadi peningkatan hasil belajar IPA secara signifikan dan dapat dikatakan tuntas secara klasikal. Penerapan model pembelajaran ini juga mengukur kterampilan literasi sains siswa, hasil observasi keterampilan literasi sains. hasil observasi keterampilan literasi sains penerapan model pembelajaran Discovery learning, diperoleh dari 26 siswa yang ada di kelas VII SMP Negeri 2 Binjai Kab. Langkat, sebanyak 21 orang siswa keterampilan literasi sainsnya dikategorikan Baik, dan 5 orang siswa keterampilan literasi sainsnya dikategorikan Cukup.Dalam keterampilan literasi sains ini, yang masih belum maksimal adalah keterampilan komunikasi siswa.

Pada Siklus I penerapan model pembelajaran Discovery learning memperoleh hasil belajar siswa dari 26 orang siswa diperoleh 18 orang yang tuntas dengan $69,2 \%$ dan 8 orang yang tidak tuntas dengan $30,8 \%$. Pada siklus 1 ini hasil belajar siswa sudah meningkat cukup baik, namun masih belum tercapai ketuntasan klasikal. Beberapa temuan yang menjadi bahan refleksi pada siklus I yaitu siswa terkendalam dalam mengumpulkan data dan mengolah data. observasi keterampilan literasi sains penerapan model pembelajaran Discovery learning, diperoleh dari 26 siswa yang ada di kelas VII SMP Negeri 2 Binjai Kab. Langkat, sebanyak 11 orang siswa keterampilan literasi sainsnya dikategorikan Baik, dan 11 orang siswa keterampilan literasi sainsnya dikategorikan Cukup, dan 4 orang siswa keterampilan literasi sainsnya dikategorikan Kurang. Dari data tersebut diketahui ada 3 aspek yang masih lemah yaitu: 1) rasa ingin tahu siswa, 2) respon terhadap data/fakta; 3) komunikasi siswa masih kurang. Dan ketiga aspek ini masih perlu diperhatikan guru untuk meningkatkannya.

Pada Siklus II diperoleh hasil belajar dari ari 26 orang siswa diperoleh 23 orang yang tuntas dengan $88,5 \%$ dan 3 orang yang tidak tuntas dengan $11,5 \%$. hasil observasi keterampilan literasi sains penerapan model pembelajaran Discovery learning, diperoleh dari 26 siswa yang ada di kelas VII SMP Negeri 2 Binjai Kab. Langkat, sebanyak 21 orang siswa keterampilan literasi sainsnya dikategorikan Baik, dan 5 orang siswa keterampilan literasi sainsnya dikategorikan Cukup.Dalam keterampilan literasi sains ini, yang masih belum maksimal adalah keterampilan komunikasi siswa. Dari pertemuan dua siklus ini, dapat ditarik kesimpulan bahwa penerapan model pembelajaran Discovery learning dapat meningkatkan hasil belajar siswa dan keterampilan literasi sains siswa temuan ini sejalan dengan temuan penelitian Yaumi (2017) Hasil analisis N-Gain ratarata pencapaian literasi sains siswa mengalami peningkatan sebesar 0,41 dan 0,35 dengan kategori sedang. Rata-rata pencapaian literasi sains siswa berada pada level 2 dan terjadi peningkatan berada pada level 4. Siswa memberikan respons positif terhadap proses pembelajaran discovery learning yaitu sebesar $92,9 \%$ dan $94,1 \%$.

\section{KESIMPULAN}

Berdasarkan temuan hasil penelitian dapat ditarik kesimpulan bahwa pada Siklus I penerapan model pembelajaran Discovery learning memperoleh hasil belajar siswa dari 26 orang siswa diperoleh 18 orang yang tuntas dengan $69,2 \%$ dan 8 orang yang tidak tuntas dengan 30,8\%. Observasi keterampilan literasi sains penerapan model pembelajaran Discovery learning, diperoleh dari 26 siswa yang ada di kelas VII SMP Negeri 2 Binjai Kab. Langkat, sebanyak 11 orang siswa keterampilan literasi sainsnya dikategorikan Baik, dan 11 orang siswa keterampilan literasi sainsnya dikategorikan Cukup, dan 4 orang siswa keterampilan literasi sainsnya dikategorikan Kurang. Pada Siklus II diperoleh hasil belajar dari ari 26 orang siswa diperoleh 23 orang yang tuntas dengan $88,5 \%$ dan 3 orang yang tidak tuntas dengan $11,5 \%$. hasil observasi keterampilan literasi sains penerapan model pembelajaran Discovery learning, diperoleh dari 26 siswa yang ada di kelas VII SMP Negeri 2 Binjai Kab. Langkat, sebanyak 21 orang siswa keterampilan literasi sainsnya dikategorikan Baik, dan 5 orang siswa keterampilan literasi sainsnya dikategorikan Cukup. Dapat ditarik kesimpulan bahwa penerapan model pembelajaran Discovery learning dapat meningkatkan hasil belajar siswa dan keterampilan literasi sains siswa Kelas VII-1 SMP Negeri 2 Binjai Kab. Langkat TP. 2017/2018.

\section{DAFTAR PUSTAKA}


Depdiknas. 2006. Kurikulum Tingkat Satuan Pendidikan (KTSP). Jakarta: Pendidikan Nasional.

Hosnan, M. 2014. Pendekatan Saintifik dan Konstektual dalam Pembelajaran Abad 21. Bogor: Penerbit Ghalia Indonesia.

Isnawati, 2014. Profil Keterampilan Proses Sains Terpadu Siswa SMP Negeri 6 Banjarmain (Pdf Online). Jurnal Inovasi Pendidikan Sains, Vol 5, No.2. (http://ppjp.unlam.ac.id/journal/index.php/ quantum/article/viewFile/1204/1050,Diakse s pada tanggal 20 Januari 2016).

Simatupang, H., Aryeni, Purnama, D .2017. Peningkatan Kemampuan Literasi Sains Mahasiswa Melalupenerapan Model Problem Solving Laboratory Pda matakuliah Praktikum Biology Sistem. Jurnal Pelita Pendidikan Vol 5. No.2. pISSN : 2338 - 3003. elSSN : $2502-3217$

Yaumi. 2017. Penerapan Perangkat Model Discovery Learning Pada Materi Pemanasan Global Untuk Melatih Keterampilan Literasi Sains Siswa SMP Kelas VII.Jurnal Pendidikan Sains. Vol.5 No.1 tahun 2017. 